J. Dairy Sci. 92:811-825

doi:10.3168/jds.2008-1476

(C) American Dairy Science Association, 2009.

\title{
Invited review: Proteomics of milk and bacteria used in fermented dairy products: From qualitative to quantitative advances
}

\author{
V. Gagnaire, ${ }^{1}$ J. Jardin, G. Jan, and S. Lortal \\ Institut National de la Recherche Agronomique, Unité Mixte de Recherche 1253, Sciences et Technologie du Lait et de l'Oeuf, \\ F-35000 Rennes, France
}

\begin{abstract}
Proteomics is a powerful tool that can simultaneously analyze several hundred proteins in complex mixtures, either through the use of high-resolution 2-dimensional gel electrophoresis or by mono- and multi-dimensional liquid chromatography coupled with mass spectrometry. Since the last review in 2005, proteomics has mainly been applied to describe minor proteins in the bovine milk fat globule membrane and soluble proteins in human colostrum. At least 130 new minor proteins have been identified. These proteins play roles in cell signaling, host defense, and transport as suggested by sequence homology. Proteomic approaches have also been applied to milk of other species such as donkey, horse, and marsupial. Peptides produced in food matrices that can exhibit functional or bioactive properties have been identified as have the proteases leading to their release in situ. However, the most spectacular proteomic development has been in the field of bacteria used in dairy products. Proteomics has resulted in the establishment of reference maps to detect strainto-strain variations and to elucidate the mechanisms of in vitro and in vivo adaptation to environmental conditions. Proteomic analysis of bacteria entrapped in cheese has been achieved and revealed which predominant metabolic pathways are active depending on the strain. Proteomic approaches are often evoked as timeconsuming procedures that provide a list of identified proteins without efficient quantification of each one. New quantitative proteomic methods have emerged and the most promising ones and their application to dairy products and bacteria will be presented.
\end{abstract}

Key words: proteomics, lactic acid bacteria, propionibacteria, bifidobacteria

\section{INTRODUCTION}

Proteomics is a powerful tool that can simultaneously analyze several hundred proteins in complex mixtures,

Received June 23, 2008.

Accepted October 15, 2008.

${ }^{1}$ Corresponding author: valerie.gagnaire@rennes.inra.fr either through the use of high-resolution 2-dimensional gel electrophoresis (2DE) or mono- and multi-dimensional liquid chromatography (LC) coupled with MS (Mann et al., 2001; Patterson and Aebersold, 2003).

Proteomics has been applied to milk since the beginning of the 1990s. Significant advances have been made in 1) the detection and identification of new proteins, in particular minor proteins or proteins located in subcellular compartments such as the milk fat globule membrane (MFGM), 2) variations in the protein profiles depending on the mammalian species or on the stage of lactation, and 3) posttranslational modifications (glycosylation, phosphorylation, and so on), which occur at extremely high frequency, either naturally or induced by processes such as lactosylation. All of these advances have recently been discussed in 2 very comprehensive reviews (O'Donnell et al., 2004; Manso et al., 2005). However, during the last 5 yr a large increase in the identification of the minor milk proteins has been observed and these findings will help in the characterization of pathways and mechanisms that occur during lactation and give information on the biological activity and functionality of these important proteins.

Proteomic approaches have also been applied to several microorganisms used in dairy fermented products, as reviewed by Champomier-Verges et al. (2002) and Manso et al. (2005). The main bacterial species considered in these reviews were Lactococcus lactis, Streptococcus thermophilus, Lactobacillus delbrueckii ssp. lactis, Lactobacillus acidophilus, and Propionibacterium freudenreichii. A proteomics approach has been applied to establish reference maps. In parallel, adaptation of probiotic lactobacilli, bifidobacteria, and propionibacteria to digestive stress has been investigated using a proteomic approach. One proteomic study attempted to identify bacterial proteins released through lysis of the microflora in Emmental cheese, a complex dairy matrix (Gagnaire et al., 2004).

This review will focus on the advances in proteomic analysis of milk since 2004 as well as proteomic approaches to investigate the adaptation of lactic acid bacteria, propionibacteria, and bifidobacteria to milk 
processing and gastrointestinal environments. Proteomic approaches have been supported by the exponential increase in protein sequence databases from mammalian and bacterial genomes in parallel with significant progress in MS technology. Quantitative proteomics is clearly the next challenge to be overcome so that many more biological questions can be answered. Thus, this review will also present the latest developments in $2 \mathrm{DE}$ and LC quantification methods using isotopically labeled products, and their first application to dairy products.

\section{PROTEOMICS OF MILK COMPONENTS AND DAIRY PRODUCTS}

Milk is a complex mammalian fluid that contains several hundred proteins, whose range of concentration can vary by at least a factor of $10^{6}$ (Fox and Kelly, 2003; O'Donnell et al., 2004). The main proteins are caseins (about $25 \mathrm{~g} / \mathrm{L}$ of bovine milk corresponding to $78 \%$ of the total milk proteins) and whey proteins (5.4 $\mathrm{g} / \mathrm{L}$ of bovine milk: $17 \%$ total milk proteins; $\beta$-LG, 2.7 $\mathrm{g} / \mathrm{L} ; \alpha-\mathrm{LA}, 1.2 \mathrm{~g} / \mathrm{L}$; BSA, $0.25 \mathrm{~g} / \mathrm{L}$; these latter 3 proteins corresponding to $8,3.8$, and $0.8 \%$, respectively). Milk also contains a large number of minor proteins, which together represent $5 \%$ of the total milk protein and which are either soluble in whey or located in the MFGM. Because of the wide range in concentration and subcellular location, no single perfect protocol yet exists in which the entire milk proteome can be examined in its entirety.

To increase the coverage of the milk proteome, prefractionation steps have been used to reduce the sample complexity before 2DE analyses. These steps exploit different properties of the proteins (charge, hydrophobicity, and size). Detection of the more acidic, basic, and hydrophobic proteins can be improved by using different separation mechanisms, alone or in combination, such as size exclusion, reversed phase, and ion exchange chromatography. Increasing interest has also been focused on LC separations, which have several distinct advantages over 2DE. The use of a 1-dimensional or 2-dimensional (2D) LC approach permits the separation of not only the full-length native proteins but also their tryptic digests. In contrast to proteins, peptides are more soluble, have similar size, and the resulting peptide fragments are more easily ionized by the mass spectrometer (Delahunty and Yates, 2005). Moreover, peptide separations by 2D LC actually exhibit greater sensitivity, superior dynamic range, are more easily automated, and are faster than 2DE (O'Donnell et al., 2004).

The first studies in the 1990s were dedicated to the characterization of the major milk proteins (i.e., caseins and whey proteins) to determine their heterogeneity (variants, posttranslational modifications, lactosylation), their differential expression between mammalian species, and their bioactive components (O'Donnell et al., 2004; Manso et al., 2005). Interest is now more focused on the minor milk proteins to aid in the search for their biological role and implications for animal and human health (D'Ambrosio et al., 2005; Lippolis and Reinhardt, 2005; Lippolis et al., 2006; Reinhardt and Lippolis, 2006; Fong et al., 2007, 2008; Smolenski et al., 2007; Reinhardt and Lippolis, 2008). Minor proteins identified from Bos taurus in various bovine milk fractions are reported in Tables 1,2 and 3. Comprehensive tables including the names of the protein, accession numbers, method of detection, and putative function are reported in supplemental material available online (http://jds.fass.org/content/vol92/issue3/). Besides the well-known proteins xanthine dehydrogenase/ oxidase, butyrophilin, cluster of differentiation (CD) 36, and lactadherin (PAS6/7), more than 120 other proteins have been identified in the MFGM. Among them, $23 \%$ were associated with cell signaling and $11 \%$ with transport/metabolism (Reinhardt and Lippolis, 2006). Eight additional minor proteins in MFGM were identified by Fong et al. (2007) that can have functions in secretory processes and protection of the neonate from various viral and bacterial infections. In another study on bovine skim milk, whey, and MFGM fractions extracted from colostrum, late-lactation milk, and mastitic milk, 15 of the 95 proteins identified were involved in host defense (Smolenski et al., 2007).

In human colostrum, 151 minor proteins were identified, 83 of which were not previously reported in human colostrum or milk (Palmer et al., 2006). Many of the newly identified proteins could participate in important functions of colostrum such as provision of immunity, regulation of growth, and nutrient transport.

Proteomic approaches have also been applied to a lesser extent to milk from other species (e.g., donkey, horse, marsupial). Heterogeneity both in casein and whey protein fractions were shown in pony mare's milk (Miranda et al., 2004), donkey's milk (Marletta et al., 2007), and in a comparative study of human, horse, donkey, goat, sheep, cow, and water buffalo (D'Auria et al., 2005).

For the common brushtail possum (Trichosurus vulpecula), all the caseins possess various forms arising from multiple phosphorylations of proteins and glycosylation of $\alpha$ - and $\kappa$-caseins (Kuy et al., 2007). However, heterogeneity of the $\kappa$-casein further increased during lactation stages from d 17 and 71, with more basic forms of greater apparent mass present in the later stage. Such a modification could be related to altered phosphorylation and glycosylation of this protein. The altered 
Table 1. Minor proteins identified in bovine milk fat globule membrane since 2005

\begin{tabular}{|c|c|c|}
\hline Protein name & Function $^{1}$ & Ref. $^{2}$ \\
\hline Cathelicidin 1 & Antimicrobial peptide & 4 \\
\hline Calgranulins B and C & $\begin{array}{l}\text { Antimicrobial peptide; associated with } \mathrm{S} 100 \mathrm{~A} 8 \\
\text { and implicated in inflammatory response }\end{array}$ & 4 \\
\hline Peptidyl-prolyl cis-trans isomerase A (cyclophilin A) & Catalyzes cis-trans isomerisation of proline imidic peptide bond & 1 \\
\hline $14-3-3$ proteins $\gamma$ and zeta chain and $\beta / \alpha$ & Cell signaling & 3,4 \\
\hline A kinase anchor protein 4 & Cell signaling & 3 \\
\hline Glucose regulated protein $58 \mathrm{kD}$ protein disulfide isomerase-associated 3 & Cell signaling & 4 \\
\hline GTP binding proteins $\alpha 14$ subunit, GL2, $\alpha-11$ subunit and Rit 1 & Cell signaling & 3 \\
\hline GTP binding regulatory proteins $\mathrm{G}(\mathrm{I}) / \mathrm{G}(\mathrm{S}) / \mathrm{G}(\mathrm{T})$, subunit $\beta-2$ and $\mathrm{Gs} \alpha$ & Cell signaling & 3 \\
\hline Rap $1 \mathrm{~A}$ and $1 \mathrm{~B}$ & Cell signaling & 3 \\
\hline Rho GDP-dissociation inhibitor 1 & Cell signaling & 3 \\
\hline STAT5 MGF Signal transducer and activator of transcription 5B & Cell signaling & 3 \\
\hline Transforming protein Rho A & Cell signaling & 3 \\
\hline Aldehyde dehydrogenase mitochondrial (NAD) 2 precursor & Enzyme & 4 \\
\hline ATP synthase, $\mathrm{H}^{+}$transporting, mitochondrial F1 complex, $\alpha$ subunit & Enzyme & 4 \\
\hline $5^{\prime}$ nucleotidase & Fat transport/metabolism & 3 \\
\hline Acetyl-CoA carboxylase 1 & Fat transport/metabolism & 3 \\
\hline Apolipoprotein E & Fat transport/metabolism & 1,3 \\
\hline Fatty acid synthase & Fat transport/metabolism & 3 \\
\hline Fatty acid-binding protein, brain type & Fat transport/metabolism & 3 \\
\hline Long-chain-fatty-acid CoA ligase 1 & Fat transport/metabolism & 3 \\
\hline Retinal short-chain dehydrogenase/reductase & Fat transport/metabolism & 3 \\
\hline Serum amyloid A3 isoform & Fat transport/metabolism & 3 \\
\hline Excitatory amino acid transporter 3 & General transport & 3 \\
\hline Sodium and chloride dependent creatine transporter 1 & General transport & 3 \\
\hline Solute carrier family 5 and family 34 (sodium phosphate), member 2 & General transport & 3,4 \\
\hline CD9 antigen & Immune function & 3 \\
\hline Ig D heavy chain, G1 heavy chain and $M$ heavy chain & Immune function & 1 \\
\hline Toll-like receptors 2 and 4 & Immune function & 3 \\
\hline Macrophage scavenger receptor types I and II & $\begin{array}{l}\text { Mediate the binding, internalization, and processing } \\
\text { of negatively charged macromolecules }\end{array}$ & 4 \\
\hline ADP ribosylation factor 1 & Membrane/protein trafficking & 3 \\
\hline Rab $27 \mathrm{~b}, 3 \mathrm{~A}, 3 \mathrm{~B}$ and $3 \mathrm{C}$ & Membrane/protein trafficking & 3 \\
\hline SAR1B protein & Membrane/protein trafficking & 3 \\
\hline Translocon associated protein subunit $\alpha$ & Membrane/protein trafficking & 3 \\
\hline Peptidyl-prolyl isomerase (Cyclophilin I) & Protein synthesis, binding, or folding & 3 \\
\hline Profilin I & Protein synthesis, binding, or folding & 3 \\
\hline Elongation factor 1 & Protein synthesis, binding, or folding & 3 \\
\hline Heat shock $90 \mathrm{kDa}$ protein & Protein synthesis, binding, or folding & 3 \\
\hline Tight junction protein 1 & Protein synthesis, binding, or folding & 3 \\
\hline Annexins 1 and A2 & Structure & 4 \\
\hline ARP3 actin-related protein 3 & Structure & 4 \\
\hline Mucin 1, glycoprotein 2 (MUC1) & Unclear but possibly antiadhesion or immunoprotective & $1,3,4$ \\
\hline
\end{tabular}

${ }^{1}$ Some functional classification.

z ${ }^{2}$ References: 1 = Fong et al. (2007); 2 = Fong et al. (2008); 3 = Reinhardt and Lippolis (2006); 4 = Smolenski et al. (2007). 
Table 2. Minor proteins identified in bovine whey since 2005

\begin{tabular}{|c|c|c|}
\hline Protein name & Function $^{1}$ & Ref. $^{2}$ \\
\hline $\operatorname{IgA}$ & Antigen recognition & 4 \\
\hline Chitinase 3 -like 1 isoform 2 (CLP-1) & Eosinophil chemotactic properties, & 2,4 \\
\hline Nucleobindin 1 isoform 1 & Promotes production of DNA-specific antibodies & 2,4 \\
\hline$\alpha-1$-Antichymotrypsin precursor SERPIN A3-5 & & 2 \\
\hline 14-3-3 Protein $\varepsilon$ & & 2 \\
\hline Actin, $\alpha 1$, skeletal muscle & & 2 \\
\hline AMBP protein precursor & & 2 \\
\hline Angiogenin precursor & & 2 \\
\hline Antithrombin III precursor isoform 1 & & 2 \\
\hline Apolipoprotein $\mathrm{H}$ & & 2 \\
\hline Casein kinase $1, \alpha 1$ & & 4 \\
\hline CD5 antigen-like & & 2 \\
\hline Cellular repressor of E1A stimulated genes & & 2 \\
\hline Complement components $\mathrm{C} 3$ isoform, $\mathrm{C} 4, \mathrm{C} 7$ isoform $1, \mathrm{C} 8, \mathrm{C} 9$, factor $\mathrm{D}$ and factor I & & 2 \\
\hline Cysteine-rich secretory protein 2 precursor (CRISP-2) & & 2 \\
\hline DnaJ (Hsp40) homolog, subfamily B, member 9 & & 2 \\
\hline Endopins 1 and 2B & & 2 \\
\hline Epididymal secretory protein E1 & & 2 \\
\hline Factor XIIa inhibitor precursor & & 2 \\
\hline Fc fragment of IgG binding protein & & 2 \\
\hline Fibroblast growth factor binding protein & & 2 \\
\hline Gelsolin precursor (ADF) & & 2 \\
\hline$\alpha-1 B-G l y c o p r o t e i n ~ 5$ & & 2 \\
\hline$\alpha$-2-HS-glycoprotein & & 2 \\
\hline$\alpha-2 \mathrm{u}$ Globulin PGCL4 isoform 1 (similar to Equ c1 isoform 1) & & 2 \\
\hline Heparanase & & 2 \\
\hline Ig $\mathrm{k}$-chain $\mathrm{C}$ region isoform 2 & & 2 \\
\hline Ig $\lambda$-like polypeptide 1 precursor & & 2 \\
\hline IgJ chain & & 2 \\
\hline Kininogen 1 & & 2 \\
\hline Lipopolysaccharide binding protein precursor isoform 1 & & 2 \\
\hline Neutrophil gelatinase associated lipocalin precursor (NGAL) & & 2 \\
\hline Nucleobindin 2 & & 2 \\
\hline Osteopontin & & 2 \\
\hline Prosaposin & & 2 \\
\hline Quiescin Q6 isoform & & 2 \\
\hline Ribonuclease, RNase A family, 4 & & 2 \\
\hline Serine (or cysteine) proteinase inhibitor, clade A & & 2,4 \\
\hline Tetranectin precursor & & 2 \\
\hline Transthyretin (prealbumin) & & 2 \\
\hline Vitamin D binding protein precursor (DBP) & & 2 \\
\hline Zinc- $\alpha-2$-glycoprotein precursor & & 2 \\
\hline
\end{tabular}

${ }^{1}$ Some functional classification.

${ }^{2}$ References: 1 = Fong et al. (2007); 2 = Fong et al. (2008); $3=$ Reinhardt and Lippolis (2006); $4=$ Smolenski et al. (2007). 
Table 3. Minor proteins identified in different bovine milk fractions since 2005

\begin{tabular}{|c|c|c|c|c|}
\hline Protein name & Condition present $^{1}$ & Milk fraction $^{2}$ & Function $^{3}$ & Ref. $^{4}$ \\
\hline Clusterin & MidL, lateL & $\mathrm{M}, \mathrm{W}$ & Apoptosis & 1,2 \\
\hline Actin, cytoplasmic 1 ( $\beta$-actin $)$ & C, L, M, MidL & $\mathrm{S}, \mathrm{W}, \mathrm{M}$ & Cell motility & 1,4 \\
\hline Fatty acid binding protein, heart-type (MDGI) & C, L, M, lateL, MidL & $\mathrm{M}, \mathrm{W}$ & Fat transport & $1,2,4$ \\
\hline Apolipoprotein A-I & M, L, MidL & $\mathrm{S}, \mathrm{M}$ & Fat transport/metabolism & $1,3,4$ \\
\hline$\beta$-2-Microglobulin precursor (lactollin) & $\mathrm{C}$, lateL & $\mathrm{M}, \mathrm{W}$ & Immune function & 2,4 \\
\hline $\operatorname{IgG}$ & $\mathrm{M}, \mathrm{L}, \mathrm{C}$ & S, W, M & Immune function & 4 \\
\hline IgM & $\mathrm{M}, \mathrm{L}, \mathrm{C}$ & S, W, M & Immune function & 4 \\
\hline Monocyte differentiation antigen CD14 & MidL, lateL & $\mathrm{M}, \mathrm{W}$ & Immune function & 2,3 \\
\hline Peptidoglycan recognition protein & $\mathrm{M}$ & $\mathrm{S}, \mathrm{M}$ & Immune function & 4 \\
\hline Polymeric-Ig receptor precursor & C, L, MidL, lateL, M & $\mathrm{W}, \mathrm{M}$ & Immune function & $1,2,4$ \\
\hline $\begin{array}{l}\text { Lactophorin, proteose peptone } 3 \text {, glycosylation- } \\
\text { dependent cell adhesion molecule } 1\end{array}$ & M, C, L, MidL, lateL & $\mathrm{M}, \mathrm{W}$ & $\begin{array}{l}\text { Membrane associated. Highly and specifically } \\
\text { expressed in lactating mammary gland }\end{array}$ & $1-4$ \\
\hline Lymphocyte cytosolic protein 1, L-plastin (LCP-1) isoform 1 & M, lateL & $\mathrm{M}, \mathrm{W}$ & Regulation of neutrophil integrin function & 2,4 \\
\hline Heat shock $70 \mathrm{kDa}$ protein 8 & L, M, MidL & $\mathrm{M}$ & Stress response & 4 \\
\hline Adipophilin & MidL, M, C, L, lateL & $\mathrm{M}, \mathrm{W}$ & Triacylglycerol deposition, fat transport/metabolism & $1-4$ \\
\hline Enolase 1 & & $\mathrm{~S}, \mathrm{M}$ & & 4 \\
\hline Fibrinogen $\gamma$-B chain precursor & M, lateL & $\mathrm{M}, \mathrm{W}$ & & 2,4 \\
\hline Fibrinogen $\alpha$ chain precursor & M, lateL & $\mathrm{M}, \mathrm{W}$ & & 2,4 \\
\hline Isocitrate dehydrogenase 1 (NADP+) & $\mathrm{L}$, lateL & $\mathrm{M}, \mathrm{W}$ & & 2,4 \\
\hline Transferrin, serotransferrin precursor & $\mathrm{C}, \mathrm{M}, \mathrm{L}$, lateL & S, W & & 2,4 \\
\hline
\end{tabular}

${ }^{1}$ Milk from various stages of lactation or health: colostrum (C), peak lactation (L), middle of lactation (MidL), late lactation (lateL), and milk from a mastitic cow (M).

c. $\quad{ }^{2}$ Milk fractions in which the protein was identified is denoted; skim milk (S), whey (W), and milk fat globule membrane (M).

${ }^{3}$ Some functional classification.

응 ${ }^{4}$ References: 1 = Fong et al. (2007); 2 = Fong et al. (2008); 3 = Reinhardt and Lippolis (2006); 4 = Smolenski et al. (2007). 
glycosylation could change micelle size and stability as well as susceptibility of the $\kappa$-casein to proteolysis. Nine minor components of whey were differentially expressed on 2DE during lactation. Lysozyme was more abundant in the $\mathrm{d} 71$ whey, whereas the other 8 proteins (cathepsin B, clusterin, ganglioside M2 activator, late lactation protein, neutrophil gelatinase-associated lipocalin, and 3 unidentified proteins) were more abundant in the $\mathrm{d}$ 17 whey (Kuy et al., 2007). In addition, a novel glycosylated protein named very early lactation protein (VELP) was also shown as a major component of the whey. So far, very early lactation protein has not been described in any other mammalian milk. A similar protein has been identified in another marsupial, the tammar wallaby (Macropus eugenii), as well as 38 other proteins (Joss et al., 2007). Fourteen of these proteins have not previously been identified in marsupial milk (Joss et al., 2007).

Comparison between results of these studies is difficult because milk from different stages of lactation was used and various methods of preparation and separation were employed. In milk, a permanent equilibrium exists between soluble and colloidal phases, and hence, great care must be used in reaching any conclusions relative to the distribution of many proteins within different milk fractions (Table 3).

\section{Peptidomics}

Peptides together with proteins can affect both functional and biological properties of food products, and a new "omic" technique named "peptidomics" has emerged (Soloviev and Finch, 2005; Minkiewicz et al., 2008; Saz and Marina, 2008). The peptidome can be defined as the whole peptide pool present in food products or raw materials, or obtained during processing and storage. One example is the array of peptides produced by proteolysis during ripening of cheeses such as Cheddar (Singh et al., 1994), Parmigiano Reggiano (Addeo et al., 1992; Addeo et al., 1994), Grana Padano (Ferranti et al., 1997), and Emmental (Gagnaire et al., 2001). Food peptidomics provides information about product authenticity, origin, and history, biological activities of peptides, functional properties, allergenicity, and sensory properties. In dairy products, many studies have been dedicated to identify peptides displaying various biological activities (Fitzgerald and Murray, 2006; Korhonen and Pihlanto, 2006). Ferranti et al. (2004) studied casein proteolysis in human milk collected from mothers of pre-term and full-term infants in the first week after parturition to trace the pattern of casein breakdown and the formation of potential bioactive peptides by the use of tandem MS. The greater susceptibility of human milk to casein proteolysis compared with bovine milk was confirmed. A large number of peptides were identified and most of them were derived from $\beta$-casein through the combined action of a plasmin-like enzyme and endo- or exopeptidases. Some bioactive peptides were found only in normal milk: $\beta_{\mathrm{H}^{-}}$-casomorphin $(1-8)$ [sequence $\beta-\mathrm{CN}(51-58)], \alpha_{\mathrm{s} 1}$-casomorphin $\left[\alpha_{\mathrm{s} 1}-\mathrm{CN}(158-\right.$ $162)]$, and an antithrombotic peptide from $\kappa$-casein [ $\kappa$ CN(98-162)] (Ferranti et al., 2004). Conversely, only the largest precursors were observed in the pre-term milk. This showed the dynamic nature of maternal milk, which seems capable of providing a succession of potentially bioactive peptides to the newborn infant. Numerous other studies have focused on bioactive peptides from bovine milk and, in particular, on the antihypertensive peptides (Gomez-Ruiz et al., 2002; Hernandez-Ledesma et al., 2004; Gomez-Ruiz et al., 2006; Quiros et al., 2006, 2007; da Costa et al., 2007; Hayes et al., 2007; Hernandez-Ledesma et al., 2007) and to a lesser extent on antimicrobial peptides (Rizzello et al., 2005; Lopez-Exposito et al., 2006; Losito et al., 2006), and phosphopeptides as mineral carriers (Lund and Ardo, 2004).

The analytical approach used in peptidomics covers the development of computational tools for the identification of peptides and their protein precursors, including genetic variants and chemical and enzymatic modifications by MS (Minkiewicz et al., 2008). Peptides result from the activity of various proteolytic enzymes. In addition to the action of plasmin in milk, other proteinases can be present in milk after leakage of somatic cells, which comprise neutrophils, macrophages, lymphocytes, and some epithelial cells, during mastitis (Le Roux et al., 2003; Wedholm et al., 2008). Such proteolytic action in milk with high SCC may have negative consequences for milk quality. Some peptides identified in milk with high SCC showed the potential activity of elastase, cathepsin B, cathepsin D, or a combination, as well as other unidentified proteinases (Wedholm et al., 2008). When protein profiling of bovine milk produced by cows with subclinical mastitis was performed by matrix-assisted laser desorption ionization (MALDI) MS, cathepsins D and G were shown to have predominant proteolytic activity (Napoli et al., 2007).

\section{PROTEOMICS OF BACTERIA USED IN FERMENTED DAIRY PRODUCTS}

Various bacteria - lactic acid bacteria, bifidobacteria, and dairy propionibacteria - are used in dairy processing for their technological or probiotic properties. Reference proteomic maps have been established from strains grown either in synthetic medium or in milk. Expression patterns differ depending on the medium, strain, and the stress applied, and hypotheses have 
been created regarding the metabolic pathways and proteins involved. However, some limitations have to be underlined: so far, 2D proteomic approaches have allowed the simultaneous detection of a maximum of about 700 proteins, which is about one-third of the open reading frame deduced from the genomes of most dairy bacteria. In particular, envelope proteins, because of their hydrophobicity, are mostly excluded from the analysis. However, innovative in vivo proteomic studies as well as studies in situ in dairy products have been developed and are presented below.

\section{Early 2D Investigations and Reference Maps}

Although proteomic studies are essentially based on a comparative approach, the preparation of a complete and reproducible reference gel is a prerequisite. Over the last $10 \mathrm{yr}$, in vitro reference maps as well as proteins overexpressed following stress adaptation have been established for most bacteria useful for dairy processing grown in either synthetic medium or in milk. For lactic acid bacteria, these have been established for Lc. lactis (Anglade et al., 2000; Drews et al., 2004; Gitton et al., 2005), Lb. delbrueckii ssp. bulgaricus (Gouesbet et al., 2002), Lactobacillus casei (Maze et al., 2004), Lb. acidophilus (Wang et al., 2005), Lactobacillus salivarius (Kelly et al., 2005), Lactobacillus plantarum (Cohen et al., 2006), and Strep. thermophilus (Perrin et al., 2000; Guimont et al., 2002a; Arena et al., 2006). A proteomic approach has also been performed on dairy propionibacteria (Jan et al., 2001; Leverrier et al., 2003), in which 733 distinct spots were visualized, while the genome analysis predicted 2,439 open reading frames (H. Falentin, INRA, UMR1253, STLO, Rennes, France; personal communication), and variations were also observed depending on the strain and adaptation conditions. A first inventory of Bifidobacterium longum NCC2705 proteins has only recently been reported by Yuan et al. (2006). In the $\mathrm{pH} 4$ to 7 range, 708 spots corresponding to 369 different proteins were identified by MS, corresponding to $21.4 \%$ of the predicted 1,727 open reading frames. This study constituted the first reference map for this important probiotic bacterium. The proteomic profile was shown to vary in vitro depending on the carbon source used by $B$. longum. An alternative method was proposed by Vitali et al. (2005). They performed a gelfree inventory of the Bifidobacterium infantis proteome using the MudPIT methodology. Vitali et al. (2005) identified 136 proteins, including high mass and basic isoelectric point proteins generally not resolved on $2 \mathrm{D}$ gels.

\section{Proteomics and Adaptation of Bacteria to Milk and Dairy Products}

Thermal stress is one of the stresses generally encountered during milk processing. The effect of this stress on bacteria has been investigated using a proteomic approach (Wouters et al., 2001; Gouesbet et al., 2002; Guimont et al., 2002b; Wang et al., 2005; Anastasiou et al., 2006). A general feature of thermal stress adaptation is the induction of chaperones and proteases involved in protein turnover. Thermotolerant variants are associated with overexpression of such proteins (Gouesbet et al., 2002; Anastasiou et al., 2006).

Using proteomic approaches, cheese processing was shown to impose harsh stress conditions on bacteria. The heat stress response of Lactobacillus helveticus PR4 during propagation in cheese whey was found to involve expression of 48 proteins related to heat adaptation. Among these were stress proteins (e.g., DnaK and GroEL), glycolysis-related machinery (e.g., enolase and GAPDH), and other regulatory proteins or factors (e.g., DNA-binding protein II and ATP-dependent protease; Di Cagno et al., 2006).

Stress proteins from $P$. freudenreichii, Lb. helveticus, and Strep. thermophilus were found to be highly expressed in Emmental cheese (Gagnaire et al., 2004) showing adaptation of bacterial species to various stresses that occur during cheese manufacturing and ripening, such as acid, thermal, and osmotic stresses. This result is consistent with the observation that this food matrix confers enhanced tolerance toward digestive stresses (Jan et al., 2000); that is, greater resistance to acid and bile stresses encountered during passage into intestinal tract, compared with pure cultures of the same propionibacterium strain. A similar protective effect was observed for yogurt-type fermented milks in vitro (Leverrier et al., 2005) and in vivo (Herve et al., 2007).

Using both metabolomic and proteomic approaches, the differential behavior of 2 strains of Lc. lactis was investigated in a model cheese made from milk concentrated by ultrafiltration (Gitton et al., 2008). Bacterial cells were harvested at $\mathrm{d} 1$ and 7 and 2D electrophoresis was performed. A total of 300 spots were identified by MS; 60 of which were specific to each strain. The main differences concerned enzymes involved in metabolism of purines/pyrimidines, lactose, and citrate. This work represents the first proteomic map of bacteria entrapped in a model of solid dairy matrix and opened the way to explore the bacterial proteome in all cheese varieties. 


\section{Proteomics and Adaptation of Bacteria to Acid and Bile Stresses}

Fermented dairy products constitute the main food source of bacteria beneficial for health - the so-called probiotics. Acid stress is the major limit to bacterial growth in fermented products and to survival in vivo in the gastrointestinal tract. Adaptation to bile limits probiotic efficacy in vivo. Effects of both stresses on the proteome of probiotic bacteria have been studied.

Stress adaptations have been reviewed for lactic acid bacteria in general by Champomier-Verges et al. (2002) and specifically for lactobacilli by De Angelis and Gobbetti (2004). A common feature to acid adaptation in all species studied is the overexpression of the conserved molecular chaperones involved in protein folding, including GroES, GroEL, DnaK, and DnaJ. Indeed, DNA and protein repair enhancement is a conserved response common to many adaptive mechanisms. In addition to these, acid adaptation also caused overexpression of enzymes involved in protein turnover (Clp protease) and different modulations of proteins involved in energy metabolism and nucleotide synthesis in $L b$. delbrueckii ssp. bulgaricus (Streit et al., 2008). In Lb. reuteri, 40 proteins were modulated by acid adaptation. They are involved in diverse cell processes and were distributed into 6 major classes: 1) transport and binding proteins; 2) transcription-translation; 3) nucleotide metabolism and amino acid biosynthesis; 4) carbon energy metabolism; 5) $\mathrm{pH}$ homeostasis and stress; and 6) unassigned. Although some stress proteins are specific to one stress, others can respond to a set of stimuli. This is the case of glycolytic enzymes such as those involved in the pentose-phosphate pathways in Lb. reuteri (Lee et al., 2008). Modulation of these proteins indicates that the cells undergo metabolic changes that may help them cope with new energy demands and maintain a transmembrane potential.

Previous studies on the adaptation of $P$. freudenreichii to acid stress at $\mathrm{pH} 4.5$ or to moderate doses of bile salts showed that such adaptation conditions confer total survival to a subsequent extreme acid challenge at $\mathrm{pH} 2.0$ and tolerance toward elevated doses of bile salts above those encountered in the human gut, respectively (Jan et al., 2000; Leverrier et al., 2003). The study of the corresponding adaptation-inducible proteins led to the establishment of an annotated reactive map (Leverrier et al., 2004). Acid adaptation enhanced the expression of proteins involved in protein and DNA repair, translation, glycolysis, and propionic fermentation. Adaptation to bile salts induces expression of proteins involved in stress perception, signal transduction, and reactive oxygen species remediation, molecular chaperones, and proteins involved in energy metabolism. Enzymes of propionic fermentation, including methylmalonyl transcarboxylase, were overexpressed during both acid and bile adaptation. Moreover, P. freudenreichii methylmalonyl transcarboxylase, one of the main stress proteins induced by both acid and bile salts stress, was expressed during the transit through the digestive tract of rats and humans (Herve et al., 2007; Lan et al., 2007).

Recently, low-pH adaptation and acid tolerance have been investigated using a proteomic approach in $B$. longum NCIMB8809 and its acid-tolerant derivative 8809dpH (Sanchez et al., 2007a). Both adaptation and tolerance responses enhanced the expression of enzymes of the carbon catabolic pathway, including those involved in complex carbohydrate degradation, bifid shunt, and branched-chain amino acid catabolism. This response should lead to enhanced carbon utilization, including amino acids as alternative carbon sources, and thus to greater ATP levels and increased proton extrusion. In vitro, bile extracts triggered general stress response chaperones and proteins involved in transcription and translation in B. longum NCIM8809, as reported by Sanchez et al. (2005), using similar 2D gels. In vitro, bile salts induced in $B$. longum changes in the metabolism of carbohydrates, amino acids, and nucleotides, suggesting a complex physiological response to the intestinal environment.

\section{Proteomics and In Vivo Adaptation to Intestinal Conditions}

The physiology of lactic acid bacteria in the gastrointestinal tract has been studied by in vivo expression technology that yields information on genes essential for the colonization or specific expression in the digestive environment (Bron et al., 2004). However, few studies have given a global view of the physiology of these bacteria in such an environment. One study by Roy et al. (2008) combined a model of axenic mice monoassociated with Lc. lactis IL2661 with a proteomic analysis of the cytoplasmic content of bacteria isolated from the feces or intestinal contents. They observed that the cecum rather than the feces was the favorite niche of Lc. lactis in monoxenic mice. Only 51 of the identified protein spots were differentially expressed between Lc. lactis isolated from feces and Lc. lactis grown in M17 medium. Among these variable proteins, 27 were upregulated and 24 downregulated compared with cells grown in M17. Three stress-related proteins were upregulated in the mouse gut and 2 of them were associated with the oxidative stress response, DNA binding protein from starved cells (DpsA) and superoxide dismutase (SodA), as reported in vitro during acid adaptation of this bacterium (Budin-Verneuil et al., 2005). There was also an induction of proteins involved 
in the catabolism and transport of alternative carbon sources in vivo, suggesting that Lc. lactis simultaneously activates several energy-producing pathways in the gastrointestinal tract. Among them, the upregulation of glucose-6-phosphate-1-dehydrogenase (G6PDH) could be associated with detoxification function.

Yuan et al. (2008) conducted an original proteomic study of B. longum NCC2705 adaptation to the intestinal environment. A culture of B. longum was placed in the intestine of a rabbit or, as control, left in de Man, Rogosa, and Sharpe medium at $37^{\circ} \mathrm{C}$. Differential proteomic analysis of the 2 cultures revealed overexpression in the intestine of many well-known adaptation proteins such as chaperones, trigger factor chaperone, ATP-dependent and Clp protease, proteins involved in translation, and transcriptional regulators. These stress proteins were also induced by various stresses such as salt stress, mild acid stress, and UV irradiation in $B$. longum $\mathrm{NC2705}$. Such induction reflects the stressful conditions encountered within the intestine and indicates the ability of this bacterium to trigger an adequate cell response for adaptation to this environment. Interestingly, proteins related to carbon metabolism, especially the bifid shunt pathway, were also induced in the intestine (Yuan et al., 2008), as described in vitro during adaptation to bifidobacteria to acid stress (Sanchez et al., 2007a) and bile salt stress (Sanchez et al., 2005). The stimulus for induction within the intestine is most probably the presence of bile salts. Indeed, bile salt exposure triggers in vitro overexpression of xylulose 5-phosphate/fructose 6-phosphate phosphoketolase, the key enzyme of the bifid shunt, and several other enzymes of the carbon catabolic pathway in B. longum NCIMB8809 (Sanchez et al., 2005). These enzymes, together with carbohydrate hydrolyzing enzymes, may provide an advantage to $B$. longum in the use of fiberderived oligosaccharides, a key component of bifidobacteria adaptation to the intestine, including nutritional competition.

The expression of a bile salt hydrolase was also induced in vivo in B. longum NCC2705, probably by the presence of its substrate, bile salts. Moreover, phosphorylation of autoinducer- 2 production protein LuxS was enhanced, suggesting involvement of the regulation of quorum sensing in intestinal adaptation. A similar approach was applied to study differences between $B$. animalis ssp. lactis IPLA4549 and its bile-resistant derivative $4549 \mathrm{dOx}$ (Sanchez et al., 2007b). Some of the bile salt-inducible proteins were constitutively overexpressed in the derivative, whereas others were induced by bile in both. These bile adaptation proteins were identified as enzymes involved in the carbon catabolic pathway and the bifid shunt, as in B. longum, plus proteins involved in formate/oxalate metabolism. Bile adaptation also comprised overexpression of several proteins involved in the redox status of the cells, including methionine synthase, keto-acid reductoisomerase, and $\mathrm{O}$-acetylhomoserine sulfhydrolase. Accordingly, the redox ratio was higher within the mutant strain and further enhanced by the presence of bile.

It should be noticed that spontaneous mutants of $B$. infantis, resistant to rifaximin, also display overexpression of chaperonins (groES, GroEL) and classical stress proteins including regulatory factors and metabolic enzymes (Vitali et al., 2007). The tolerance of this mutant toward digestive stresses, unfortunately, was not investigated in this study. However, the authors propose this spontaneous mutant as a probiotic aimed at treating gastrointestinal disease in conjunction with antibiotics.

In 2D gels and Western blot assay, Candela et al. (2007) confirmed the binding of human plasminogen to B. lactis BI07. They first reported the interaction of this glycoprotein with diverse bifidobacteria species. Then, a cell wall fraction of BI07 was separated on a 2D gel, and transferred onto a membrane that was used for the interaction assay. The results suggest binding of plasminogen to the surface-located chaperone DnaK and, to a lesser extent to enolase. Such a binding, already shown for intestinal pathogens, may constitute an advantage in colonizing the human gastrointestinal tract.

\section{TOWARD QUANTITATIVE PROTEOMICS}

Although the main objective of proteomics research is the systematic identification of proteins, the next step will be to bridge the gap between identification and quantification of proteins with quantitative estimates of differential expression of milk proteins during lactation, as well as changes in milk composition during technological processes. Elucidation of proteins expressed by the microflora is essential to understand bacterial metabolism. Knowing how the abundance of the proteins expressed varies in situ over time will provide important information about microbial adaptation to changing environmental parameters. Such knowledge will also allow elucidation of the changes in the mixture composition and relative protein abundance under differing physiological conditions.

The last 10 yr have been rich in emergent quantitative technologies based either on gel electrophoresis or on chromatographic separations and mass spectrometry analyses.

\section{Quantitative Proteomics: Principle and Reagents}

Generally, differential protein expression has been studied by $2 \mathrm{DE}$ and direct comparison of gels after 
classical staining (Coomassie Blue or silver nitrate) or autoradiography. This approach requires statistical analyses of numerous sets of gels to circumvent variability between them. Two-dimensional difference gel electrophoresis (2D DIGE) presented by Ünlü et al. (1997) represents a real advance in protein quantitation by $2 \mathrm{D}$ electrophoresis. This technique consists of covalently derivatizing proteins with fluorophores in complex protein mixtures before $2 \mathrm{D}$ gel electrophoresis. The technique is robust and allows for a gain in sensitivity and quantitative analyses of a wide dynamic range of 4 to 5 orders of magnitude. Detection and quantification of the differences in the abundance of proteins between different biological samples are therefore possible within a single gel, except if proteins present had highly acidic, basic, or hydrophobic properties, or are present at very high or low concentrations (Wu et al., 2006). Advantages of using fluorescent labeling include the ability to label biological samples during their growth and the rapidity and simplicity of labeling without modification of culture conditions. The 2D-DIGE method has largely been applied for biomarker purposes in cancer therapy (for reviews, see Fenselau, 2007; Hoffman et al., 2007) but to date no study has been performed in dairy products or in probiotic bacteria to our knowledge.

To circumvent the limitations of $2 \mathrm{D}$ gels, great advances have taken place in chromatographic separation of samples and online coupling with MS. This technique requires specific labeling because 1) ionization yield for molecules with different molecular formulae is not the same; and 2) intensity of ion detection by electron multiplier is dependent on the molecular mass of the detected ions. The labeling techniques involve differential isotopic composition of molecules with identical chemical structures to bypass these limitations. Different techniques using isotopic labeling have been developed for protein or peptide labeling: isotope coded affinity tag (ICAT) technology (Applied Biosystems, Foster City, CA) and isobaric tagging for relative and absolute quantitation (iTRAQ, Applied Biosystems).

The ICAT technology, the first isotopic labeling presented in the literature, uses isotopic labeling of cysteine residues by using a light or heavy tag containing biotinylated reagents differing by 8 Da (Gygi et al., 1999). The 2 samples derivatized with the isotopic light or heavy reagent are combined and enzymatically cleaved, generally with trypsin, to generate peptide fragments that are further analyzed by LC coupled online with MS/MS (tandem MS). The specificity of the ICAT labeling technique to cysteine residues renders it less widely used than, for example, the iTRAQ labeling strategy because about $15 \%$ of proteins do not contain any cysteine residues.
The iTRAQ technique, commercially available since 2004 , has been exponentially used since its introduction and permits relative quantitation of 2 to 8 samples simultaneously (Choe et al., 2007). It has been utilized in very different fields such as biomarker discovery (Fenselau, 2007), elucidation of cellular signaling pathways (Sui et al., 2007), posttranslational modification analysis such as phosphorylation (Sachon et al., 2006), correlations between genomic and proteomics (Scherl et al., 2006), time-course analysis (Cong et al., 2006; Jagtap et al., 2006), bacterial analysis (Chong et al., 2006; Danielsen et al., 2007), and membrane or subcellular analysis (Lund et al., 2007). The iTRAQ technique was first applied to Saccharomyces cerevisiae to identify global protein expression trends in a set of isogenic yeast strains by Ross et al. (2004). In contrast to ICAT, differentially labeled peptides appear as single peaks in MS thanks to the presence of a mass balancing moiety that render all labels isobaric. During MS/MS fragmentation, the isotope-encoded reporter ions are released to allow relative quantification. This method has the double advantage of permitting the identification of the proteins and their quantification in a single LC-MS/ MS run.

In a comparative study of 2D DIGE, cleavable ICAT, and iTRAQ quantification methods, Wu et al. (2006) used reconstituted protein mixtures containing 6 proteins from bovine (BSA, $\beta-\mathrm{LG}, \alpha-\mathrm{LA}$ ) or other origin (lysozyme, aprotransferrin, and $\beta$ galactosidase, or human plasma depleted in major proteins). Results of the comparison showed that all 3 methods yielded good quantitation of the proteins when applied to a relatively complex sample and gave complementary information. However, partial or complete comigration of proteins in 2D DIGE diminished the accuracy of quantification. The cICAT method was shown to be as sensitive as $2 \mathrm{D}$ DIGE but failed to detect proteins without cysteine residues. Although iTRAQ was considered the most sensitive method, the reliability of the results obtained depended on the time-ion selector resolution chosen on the mass spectrometer used, in that case MALDI-time of flight-time of flight. The iTRAQ technique was also shown to avoid the problems of quantitation due to multiple protein spots or comigration of protein inherent to 2D gel quantitation (Wolff et al., 2006). Regardless of technique, a difficulty remains for the proteins present at very low signal-to-noise ratio whether quantitation is gel-based or gel-free.

For bacterial growth studies, other less commonly used methods have been utilized to obtain metabolic information. Stable isotope from amino acids in cell culture (SILAC) can be incorporated into proteins during growth (Ong et al., 2002; Coute et al., 2007). How- 
ever, the disadvantage of the technique is the doubling of the peaks during chromatography and the difficulty in the interpretation of the resulting mass spectra. Another method, surface-enhanced laser desorption ionization-time of flight (SELDI-TOF), has been applied to different bifidobacteria species grown on different carbohydrates (lactose, glucose, galactose) to identify enzymes specifically expressed in response to the presence of these substrates. One such technique uses a protein chip array, which has varying chromatographic properties, such as anion exchange, cation exchange, metal affinity, and reverse phase and is combined with MS. The level of expression of cytoplasmic proteins was different according the nature of the carbohydrate used for growth in terms of number and intensity. The differentially expressed proteins were further shown as enzymes involved in the metabolism of these carbohydrates using SDS-PAGE coupled to LC-MS/MS (He et al., 2007). The proposed method may prove useful in studying carbohydrate metabolism in complex ecosystems.

\section{Quantitative Proteomics: Application to Milk and Dairy Products}

In the dairy field, few studies have yet been performed using quantitative proteomics; the studies that have been done used iTRAQ. The first example is given by Lippolis et al. (2006), who labeled the bovine neutrophil proteome and assessed the changes in neutrophil protein expression under different experimental conditions. They contrasted the proteomes of prepartum neutrophils (obtained $28 \mathrm{~d}$ before calving) to those isolated within $3 \mathrm{~d}$ of calving to examine relative changes in neutrophil protein expression associated with neutrophil immunosuppression at parturition in dairy cows. More than 40 proteins were found to be differentially expressed at parturition compared with prepartum. In addition, when cows were treated with an immunosuppressive dose of glucorticoid (dexamethasone), more than 70 proteins were differentially expressed. Identification of which proteins are differentially regulated during immunosuppression may lead to a greater understanding of the pathways and mechanisms that lead to immunosuppression. It may also point toward new research into therapeutics that could reverse dysfunction of immune cells and thus aid in reducing the incidence of mastitis. A second example is focused on the quantification of up- and down-regulation of protein from MFGM when they are secreted in colostrum at $\mathrm{d} 1$ and milk at $\mathrm{d} 7$ after parturition (Reinhardt and Lippolis, 2008). These authors identified and quantified more than 130 proteins from MFGM using iTRAQ technology. Among them, $70 \%$ were identified as membrane-associated proteins, whereas the others were cytosolic or secreted proteins. A total of 26 proteins were up-regulated in milk on d 7 of lactation compared with colostrum. Among them, adipophilin, butyrophilin, and xanthine dehydrogenase were individually up-regulated at the same time. The other up-regulated proteins have functions associated with protection of the cow or calf from infection (mucin 15 and mucin 1) and with lipid transport, synthesis, and secretion [acyl-CoA synthetase, lanosterol synthase, lysophosphatidic acid acyltransferase, cell deathinducing DFFA-like effector A (CIDEA), and fatty acid binding protein]. In contrast, 19 proteins were downregulated in milk on d 7 of lactation compared with colostrum. Among these were lipoproteins, clusterin, and lactoferrin. The remaining identified proteins remained unchanged. Such a study emphasizes the use of proteomic analysis as a powerful tool for the better understanding of the mechanisms of lactation.

Numerous bacterial proteins have been shown to be released into Swiss-type cheese through lysis of the lactic starters Strep. thermophilus and Lb. helveticus (Gagnaire et al., 2004). Proteins including various peptidases, glycolytic enzymes, and stress proteins were identified using 2D gel electrophoresis and MS/MS. The new challenge involves the quantification of these proteins in the cheese matrix at different stages of ripening. Such a dynamic approach can give an insight into the sequential release of the bacterial proteins throughout ripening. Preliminary results were obtained on a timecourse analysis of the bacterial proteins released into experimental Swiss-type cheeses into the cheese matrix using iTRAQ labeling reagents (Gagnaire et al., 2007). These were manufactured using microfiltered milk and, as starter lactic acid bacteria, Strep. thermophilus ITGST20, Lb. helveticus ITGLH1, and dairy propionibacteria P. freudenreichi ITGP23 (Actilait, Bourg en Bresse, France). At 3 ripening times, cheese aqueous phases were extracted and fractionated to separate the bacterial proteins from the major milk proteins, mainly caseins, $\beta$-LG, and $\alpha$-LA (Gagnaire et al., 2004). Each fraction enriched in bacterial proteins was digested with trypsin and labeled with specific iTRAQ tags, one per ripening time. The labeled samples were mixed together and analyzed by nano-reversed phase LC coupled online with electrospray ionization-hybrid quadrupole time of flight MS and MALDI-hybrid quadrupole time of flight MS. An example of the quantification is given in Figure 1. Proteins arising from the 2 lactic acid bacteria starters L. helveticus and S. thermophilus as well as bovine proteins were identified in the aqueous phase of cheese. As expected, bovine proteins present in the cheese aqueous phase remained constant and bacterial proteins increased in quantity throughout ripening. Interestingly, the magnitude of the increase was differ- 


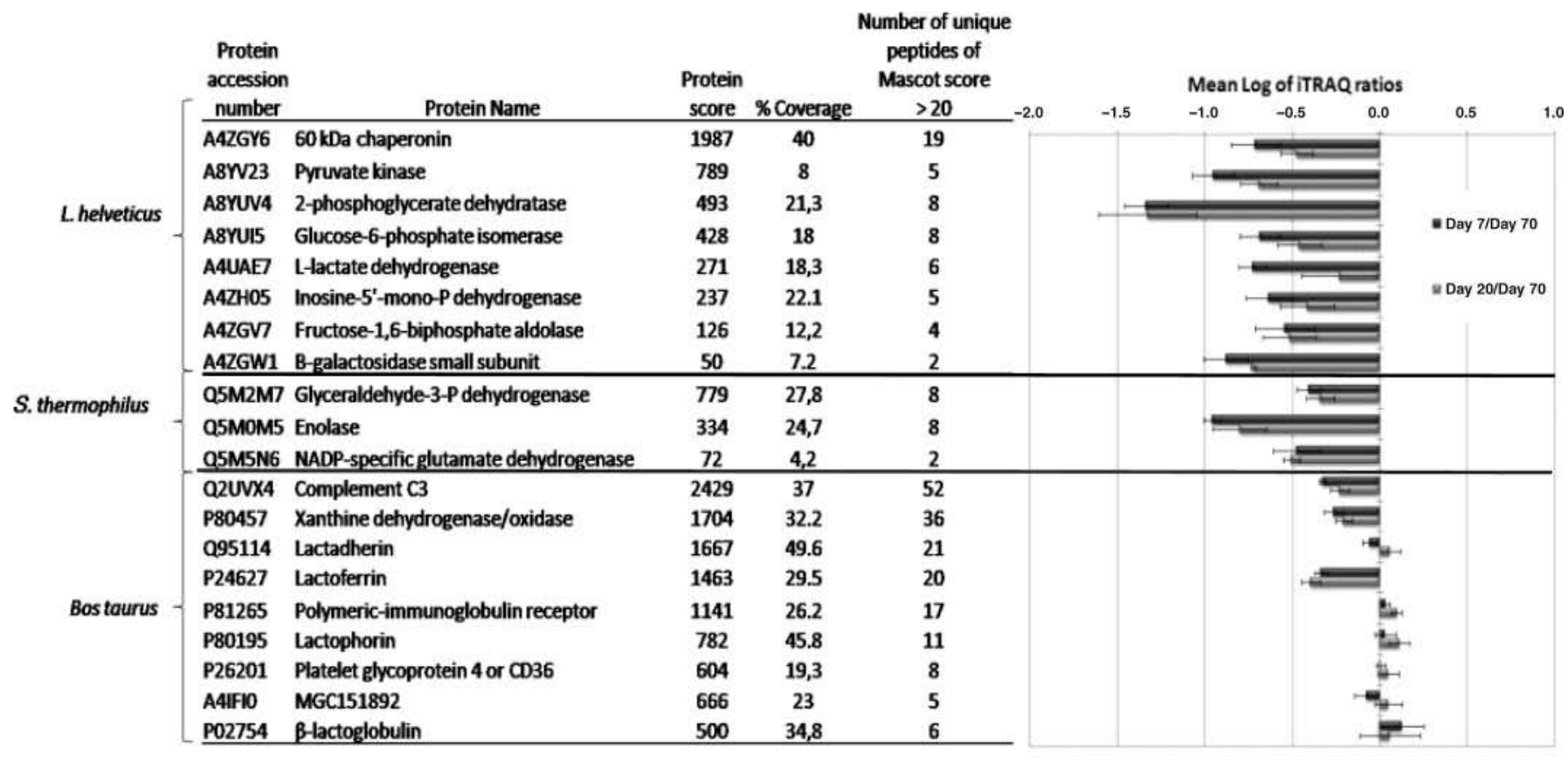

\section{(A) Examples of protein identified}

(B) Protein quantification

Figure 1. Example of protein identification and quantification by isobaric tagging for relative and absolute quantitation (iTRAQ) reagents present in the aqueous phase of Swiss-type cheese. From the same profile, identification of proteins (A) as well as their quantification (B) was achieved in the same run for the 3 ripening times. The ratios d 7:d 70 or d 20:d 70 are expressed as a logarithm. The quantity of free bacterial proteins greatly increased throughout ripening, with an average factor of 6 for both bacterial species, from d 7 to 70 of ripening. However, this increase was different according to the proteins and can vary from 5 - to 21 -fold. Bovine proteins, which should remain constant, varied only by a factor of between 0.5 and 2 . This gives an estimation of the reproducibility of the extraction and of the quantification method.

ent depending on the protein and varied from a 5- to 21-fold increase for different proteins belonging to the same species.

\section{CONCLUSIONS}

Many new minor proteins have been identified in milk over the last $5 \mathrm{yr}$, in particular in the bovine MFGM and in human colostrum. The physiological roles of these proteins must now be elucidated. Their location in the membrane or in the soluble fraction of milk can depend on the method of preparation for proteomics analysis and care must be taken in their interpretation. Peptidomics on dairy products has provided useful information about product authenticity, origin, and history, and regarding the presence of bioactive peptides. As far as dairy bacteria are concerned, in vitro proteomic studies have confirmed, in a larger number of species including probiotics, the general mechanisms of stress adaptation. Innovative in vivo experimentation has provided data regarding the proteome expressed in the gastrointestinal tract, corroborating largely what has been observed in vitro. The exploration of the proteomes of bacteria entrapped in cheese also resulted in interesting findings, highlighting the overexpression of different metabolic pathways depending on the strain, and the nature of the stresses encountered in the cheese. With the spectacular development in MS quantitative methodology, quantitative proteomics is now accessible and will be a decisive turning point in our knowledge on proteins from milk and bacteria involved in fermented dairy products.

\section{ACKNOWLEDGMENTS}

The authors are grateful to John A. Hannon (Moorepark Food Research Centre, Fermoy, Ireland) for careful reading and fruitful discussion of the manuscript.

\section{REFERENCES}

Addeo, F., L. Chianese, R. Sacchi, S. Spagna Musso, P. Ferranti, and A. Malorni. 1994. Characterization of the oligopeptides of Parmigiano-Reggiano cheese soluble in $120 \mathrm{~g}$ trichloroacetic acid/l. J. Dairy Res. 61:365-374.

Addeo, F., L. Chianese, A. Salzano, R. Sacchi, U. Cappuccio, P. Ferranti, and A. Malorni. 1992. Characterisation of the $12 \%$ trichloroacetic acid-insoluble oligopeptides of Parmigiano-Reggiano cheese. J. Dairy Res. 59:401-411.

Anastasiou, R., P. Leverrier, L. Krestas, A. Rouault, G. Kalantzopoulos, P. Boyaval, E. Tsakalidou, and G. Jan. 2006. Changes in protein 
synthesis during thermal adaptation of Propionibacterium freudenreichii subsp shermanii. Int. J. Food Microbiol. 108:301314 .

Anglade, P., E. Demey, V. Labas, J. P. Le Caer, and J. F. Chich. 2000. Towards a proteomic map of Lactococcus lactis NCDO 763. Electrophoresis 21:2546-2549.

Arena, S., C. D'Ambrosio, G. Renzone, R. Rullo, L. Ledda, F. Vitale, G. Maglione, M. Varcamonti, L. Ferrara, and A. Scaloni. 2006. A study of Streptococcus thermophilus proteome by integrated analytical procedures and differential expression investigations. Proteomics 6:181-192.

Bron, P. A., C. Grangette, A. Mercenier, W. M. De Vos, and M. Kleerebezem. 2004. Identification of Lactobacillus plantarum genes that are induced in the gastrointestinal tract of mice. J. Bacteriol. 186:5721-5729.

Budin-Verneuil, A., V. Pichereau, Y. Auffray, D. S. Ehrlich, and E. Maguin. 2005. Proteomic characterization of the acid tolerance response in Lactococcus lactis MG1263. Proteomics 5:4794-4807.

Candela, M., S. Bergmann, M. Vici, B. Vitali, S. Turroni, B. J. Eikmanns, S. Hammerschmidt, and P. Brigidi. 2007. Binding of human plasminogen to Bifidobacterium. J. Bacteriol. 189:59295936 .

Champomier-Verges, M. C., E. Maguin, M. Y. Mistou, P. Anglade, and J. F. Chich. 2002. Lactic acid bacteria and proteomics: Current knowledge and perspectives. J. Chromatogr. B Analyt. Technol. Biomed. Life Sci. 771:329-342.

Choe, L., M. D'Ascenzo, N. R. Relkin, D. Pappin, P. Ross, B. Williamson, S. Guertin, P. Pribil, and K. H. Lee. 2007. 8-Plex quantitation of changes in cerebrospinal fluid protein expression in subjects undergoing intravenous immunoglobulin treatment for Alzheimer's disease. Proteomics 7:3651-3660.

Chong, P. K., C. S. Gan, T. K. Pham, and P. C. Wright. 2006. Isobaric tags for relative and absolute quantitation (iTRAQ) reproducibility: Implication of multiple injections. J. Proteome Res. 5:1232-1240.

Cohen, D. P. A., J. Renes, F. G. Bouwman, E. G. Zoetendal, E. Mariman, W. M. De Vos, and E. E. Vaughan. 2006. Proteomic analysis of log to stationary growth phase Lactobacillus plantarum cells and a 2-DE database. Proteomics 6:6485-6493.

Cong, Y. S., E. Fan, and E. Wang. 2006. Simultaneous proteomic profiling of four different growth states of human fibroblasts, using amine-reactive isobaric tagging reagents and tandem mass spectrometry. Mech. Ageing Dev. 127:332-343.

Coute, Y., C. Hernandez, R. D. Appel, J. C. Sanchez, and A. Margolles. 2007. Labeling of Bifidobacterium longum cells with $\mathrm{C}^{13}{ }^{13}$-substituted leucine for quantitative proteomic analyses. Appl. Environ. Microbiol. 73:5653-5656.

D'Ambrosio, C., S. Arena, F. Talamo, L. Ledda, G. Renzone, L. Ferrara, and A. Scaloni. 2005. Comparative proteomic analyses of mammalian animal tissues and body fluids: bovine proteome database. J. Chromatogr. B Analyt. Technol. Biomed. Life Sci. 815:157-168.

D'Auria, E., C. Agostoni, M. Giovannini, E. Riva, R. Zetterstrom, R. Fortin, G. F. Grepp, L. Bonizzi, and P. Roncada. 2005. Proteomic evaluation of milk from different mammalian species as a substitute for breast milk. Acta Paediatr. 94:1708-1713.

da Costa, E. L., J. A. D. Gontijo, and F. M. Netto. 2007. Effect of heat and enzymatic treatment on the antihypertensive activity of whey protein hydrolysates. Int. Dairy J. 17:632-640.

Danielsen, M., H. Hornshoj, R. H. Siggers, B. B. Jensen, A. G. vanKessel, and E. Bendixen. 2007. Effects of bacterial colonization on the porcine intestinal proteome. J. Proteome Res. 6:25962604.

De Angelis, M., and M. Gobbetti. 2004. Environmental stress responses in Lactobacillus: A review. Proteomics 4:106-122.

Delahunty, C., and J. R. Yates. 2005. Protein identification using 2D-LC-MS/MS. Methods 35:248-255.

Di Cagno, R., M. De Angelis, A. Limitone, P. F. Fox, and M. Gobbetti. 2006. Response of Lactobacillus helveticus PR4 to heat stress during propagation in cheese whey with a gradient of decreasing temperatures. Appl. Environ. Microbiol. 72:4503-4514.
Drews, O., G. Reil, H. Parlar, and A. Gorg. 2004. Setting up standards and a reference map for the alkaline proteome of the Gram-positive bacterium Lactococcus lactis. Proteomics 4:1293-1304.

Fenselau, C. 2007. A review of quantitative methods for proteomic studies. J. Chromatogr. B Analyt. Technol. Biomed. Life Sci. 855:14-20.

Ferranti, P., E. Itolli, F. Barone, A. Malorni, G. Garro, P. Laezza, L. Chianese, F. Migliaccio, V. Stingo, and F. Addeo. 1997. Combined high resolution chromatographic techniques (FPLC and HPLC) and mass spectrometry-based identification of peptides and proteins in Grana Padano cheese. Lait 77:683-697.

Ferranti, P., M. V. Traisci, G. Picariello, A. Nasi, V. Boschi, M. Siervo, C. Falconi, L. Chianese, and F. Addeo. 2004. Casein proteolysis in human milk: tracing the pattern of casein breakdown and the formation of potential bioactive peptides. J. Dairy Res. 71:7487.

Fitzgerald, R. J., and B. A. Murray. 2006. Bioactive peptides and lactic fermentations. Int. J. Dairy Technol. 59:118-125.

Fong, B. Y., C. S. Norris, and A. K. H. MacGibbon. 2007. Protein and lipid composition of bovine milk-fat-globule membrane. Int. Dairy J. $17: 275-288$.

Fong, B. Y., C. S. Norris, and K. P. Palmano. 2008. Fractionation of bovine whey proteins and characterisation by proteomic techniques. Int. Dairy J. 18:23-46.

Fox, P. F., and A. L. Kelly. 2003. Developments in the chemistry and technology of milk proteins. 2. Minor milk proteins. Food Aust. $55: 231-234$.

Gagnaire, V., D. Mollé, M. Herrouin, and J. Léonil. 2001. Peptides identified during Emmental cheese ripening: Origin and proteolytic systems involved. J. Agric. Food Chem. 49:4402-4413.

Gagnaire, V., D. Mollé, J. Jardin, and S. Lortal. 2007. Quantitative proteomic analysis of bacterial enzymes released in cheese during ripening. J. Dairy Sci. 90(Suppl. 1):630. (Abstr.)

Gagnaire, V., M. Piot, B. Camier, J. P. C. Vissers, G. Jan, and J. Léonil. 2004. Survey of bacterial proteins released in cheese: A proteomic approach. Int. J. Food Microbiol. 94:185-201.

Gitton, C., E. Chambellon, G. Bergot, C. Deladrière, V. Monnet, and M. Yvon. 2008. Proteome and metabolic analysis of Lactococcus lactis in a cheese model. 5th IDF Symposium on Cheese Ripening, Bern, Switzerland. Agroscope Liebefield-Posieux Research Station ALP, Switzerland.

Gitton, C., M. Meyrand, J. H. Wang, C. Caron, A. Trubuil, A. Guillot, and M. Y. Mistou. 2005. Proteomic signature of Lactococcus lactis NCDO763 cultivated in milk. Appl. Environ. Microbiol. 71:71527163

Gomez-Ruiz, J. A., M. Ramos, and I. Recio. 2002. Angiotensinconverting enzyme-inhibitory peptides in Manchego cheeses manufactured with different starter cultures. Int. Dairy J. 12:697-706.

Gomez-Ruiz, J. A., G. Taborda, L. Amigo, I. Recio, and M. Ramos. 2006. Identification of ACE-inhibitory peptides in different Spanish cheeses by tandem mass spectrometry. Eur. Food Res. Technol. 223:595-601

Gouesbet, G., G. Jan, and P. Boyaval. 2002. Two-dimensional electrophoresis study of Lactobacillus delbrueckii subsp. bulgaricus thermotolerance. Appl. Environ. Microbiol. 68:1055-1063.

Guimont, C., M. A. Chopard, J. L. Gaillard, and J. F. Chamba. 2002a. Comparative study of the protein composition of three strains of Streptococcus thermophilus grown either in M17 medium or in milk. Lait 82:645-656.

Guimont, C., M. A. Chopard, J. L. Gaillard, and J. F. Chamba. 2002b. Composition protéique d'une souche de Streptococcus thermophilus cultivée dans le lait à $42^{\circ} \mathrm{C}$ et dans les conditions thermiques de fabrication de l'emmental. Sci. Aliments 22:59-66.

Gygi, S. P., B. Rist, S. A. Gerber, F. Turecek, M. H. Gelb, and R. Aebersold. 1999. Quantitative analysis of complex protein mixtures using isotope-coded affinity tags. Nat. Biotechnol. 17:994-999.

Hayes, M., C. Stanton, H. Slattery, O. O'Sullivan, C. Hill, G. F. Fitzgerald, and R. P. Ross. 2007. Casein fermentate of Lactobacillus animalis DPC6134 contains a range of novel propeptide angiotensin- 
converting enzyme inhibitors. Appl. Environ. Microbiol. 73:4658 4667.

He, T., H. Roelofsen, G. Alvarez-Llamas, M. de Vries, K. Venema, G. W. Welling, and R. J. Vonk. 2007. Differential analysis of protein expression of Bifidobacterium grown on different carbohydrates. J. Microbiol. Methods 69:364-370.

Hernandez-Ledesma, B., L. Amigo, M. Ramos, and I. Recio. 2004. Release of angiotensin converting enzyme-inhibitory peptides by simulated gastrointestinal digestion of infant formulas. Int. Dairy J. 14:889-898.

Hernandez-Ledesma, B., A. Quiros, L. Amigo, and I. Recio. 2007. Identification of bioactive peptides after digestion of human milk and infant formula with pepsin and pancreatin. Int. Dairy J. $17: 42-49$.

Herve, C., M. Fondrevez, A. Cheron, F. Barloy-Hubler, and G. Jan. 2007. Transcarboxylase mRNA: a marker which evidences $P$. freudenreichii survival and metabolic activity during its transit in the human gut. Int. J. Food Microbiol. 113:303-314.

Hoffman, S. A., W. A. Joo, L. A. Echan, and D. W. Speicher. 2007. Higher dimensional (Hi-D) separation strategies dramatically improve the potential for cancer biomarker detection in serum and plasma. J. Chromatogr. B Analyt. Technol. Biomed. Life Sci. 849:43-52.

Jagtap, P., G. Michailidis, R. Zielke, A. K. Walker, N. Patel, J. R. Strahler, A. Driks, P. C. Andrews, and J. R. Maddock. 2006. Early events of Bacillus anthracis germination identified by time-course quantitative proteomics. Proteomics 6:5199-5211.

Jan, G., P. Leverrier, V. Pichereau, and P. Boyaval. 2001. Changes in protein synthesis and morphology during acid adaptation of Propionibacterium freudenreichii. Appl. Environ. Microbiol. 67:2029-2036.

Jan, G., A. Rouault, and J. L. Maubois. 2000. Acid stress susceptibility and acid adaptation of Propionibacterium freudenreichii subsp. shermanii. Lait 80:325-336.

Joss, J., M. Molloy, L. Hinds, and E. Deane. 2007. Proteomic analysis of early lactation milk of the tammar wallaby (Macropus eugenii). Comp. Biochem. Physiol. D Genomics Proteomics 2:150-164.

Kelly, P., P. B. Maguire, M. Bennett, D. J. Fitzgerald, R. J. Edwards, B. Thiede, A. Treumann, J. K. Collins, G. C. O'Sullivan, F. Shanahan, and C. Dunne. 2005. Correlation of probiotic Lactobacillus salivarius growth phase with its cell wall-associated proteome. FEMS Microbiol. Lett. 252:153-159.

Korhonen, H., and A. Pihlanto. 2006. Bioactive peptides: Production and functionality. Int. Dairy J. 16:945-960.

Kuy, S., V. C. Kelly, A. M. Smit, D. J. Palmer, and G. J. Cooper 2007. Proteomic analysis of whey and casein proteins in early milk from the marsupial Trichosurus vulpecula, the common brushtail possum. Comp. Biochem. Physiol. D Genomics Proteomics $2: 112-120$.

Lan, A., A. Bruneau, C. Philippe, V. Rochet, A. Rouault, C. Herve, N. Roland, S. Rabot, and G. Jan. 2007. Survival and metabolic activity of selected strains of Propionibacterium freudenreichii in the gastrointestinal tract of human microbiota-associated rats. Br. J. Nutr. 97:714-724.

Le Roux, Y., F. Laurent, and F. Moussaoui. 2003. Polymorphonuclear proteolytic activity and milk composition change. Vet. Res. 34:629-645.

Lee, K., H. G. Lee, K. Pi, and Y. J. Choi. 2008. Effect of low pH on protein expression by the probiotic bacterium Lactobacillus reuteri. Proteomics 8:1624-1630.

Leverrier, P., D. Dimova, V. Pichereau, Y. Auffray, P. Boyaval, and G. Jan. 2003. Susceptibility and adaptive response to bile salts in Propionibacterium freudenreichii: Physiological and proteomic analysis. Appl. Environ. Microbiol. 69:3809-3818.

Leverrier, P., Y. Fremont, A. Rouault, P. Boyaval, and G. Jan. 2005. In vitro tolerance to digestive stresses of propionibacteria: Influence of food matrices. Food Microbiol. 22:11-18.

Leverrier, P., J. P. C. Vissers, A. Rouault, P. Boyaval, and G. Jan. 2004 Mass spectrometry proteomic analysis of stress adaptation reveals both common and distinct response pathways in Propionibacterium freudenreichii. Arch. Microbiol. 181:215-230.
Lippolis, J. D., B. D. Peterson-Burch, and T. A. Reinhardt. 2006. Differential expression analysis of proteins from neutrophils in the periparturient period and neutrophils from dexamethasone-treated dairy cows. Vet. Immunol. Immunopathol. 111:149-164.

Lippolis, J. D., and T. A. Reinhardt. 2005. Proteomic survey of bovine neutrophils. Vet. Immunol. Immunopathol. 103:53-65.

Lopez-Exposito, I., J. A. Gomez-Ruiz, L. Amigo, and I. Recio. 2006. Identification of antibacterial peptides from ovine alpha(s2)-casein Int. Dairy J. 16:1072-1080.

Losito, L., T. Carbonara, M. D. De Bari, M. Gobbetti, F. Palmisano, C. G. Rizzello, and P. G. Zambonin. 2006. Identification of peptides in antimicrobial fractions of cheese extracts by electrospray ionization ion trap mass spectrometry coupled to a two-dimensional liquid chromatographic separation. Rapid Commun. Mass Spectrom. 20:447-455

Lund, M., and Y. Ardo. 2004. Purification and identification of water-soluble phosphopeptides from cheese using $\mathrm{Fe}(\mathrm{III})$ affinity chromatography and mass spectrometry. J. Agric. Food Chem. 52:6616-6622

Lund, T. C., L. B. Anderson, V. McCullar, L. Higgins, G. H. Yun, B. Grzywacz, M. R. Verneris, and J. S. Miller. 2007. iTRAQ is a useful method to screen for membrane-bound proteins differentially expressed in human natural killer cell types. J. Proteome Res. 6:644-653.

Mann, M., R. C. Hendrickson, and A. Pandey. 2001. Analysis of proteins and proteomes by mass spectrometry. Annu. Rev. Biochem. 70:437-473.

Manso, M. A., J. Léonil, G. Jan, and V. Gagnaire. 2005. Application of proteomics to the characterisation of milk and dairy products. Int. Dairy J. 15:845-855.

Marletta, D., A. Criscione, V. Cunsolo, A. Zuccaro, V. Muccilli, S. Bordonaro, A. M. Guastella, and G. D’Urso. 2007. Protein fraction heterogeneity in donkey's milk analysed by proteomic methods. Ital. J. Anim. Sci. 6:650-652.

Maze, A., G. Boel, S. Poncet, I. Mijakovic, Y. Le Breton, A. Benachour, V. Monedero, J. Deutscher, and A. Hartke. 2004. The Lactobacillus casei ptsHI47T mutation causes overexpression of a LevR-regulated but RpoN-independent operon encoding a mannose class phosphotransferase system. J. Bacteriol. 186:4543-4555.

Minkiewicz, P., J. Dziuba, M. Darewicz, A. Iwaniak, M. Dziuba, and D. Nalecz. 2008. Food peptidomics. Food Technol. Biotechnol. 46:1-10.

Miranda, G., M. F. Mahe, C. Leroux, and P. Martin. 2004. Proteomic tools to characterize the protein fraction of Equidae milk Proteomics 4:2496-2509.

Napoli, A., D. Aiello, L. Di Donna, H. Prendushi, and G. Sindona. 2007. Exploitation of endogenous protease activity in raw mastitic milk by MALDI-TOF/TOF. Anal. Chem. 79:5941-5948.

O'Donnell, R., J. W. Holland, H. C. Deeth, and P. Alewood. 2004 Milk proteomics. Int. Dairy J. 14:1013-1023.

Ong, S. E., B. Blagoev, I. Kratchmarova, D. B. Kristensen, H. Steen, A. Pandey, and M. Mann. 2002. Stable isotope labeling by amino acids in cell culture, SILAC, as a simple and accurate approach to expression proteomics. Mol. Cell. Proteomics 1:376-386.

Palmer, D. J., V. C. Kelly, A. M. Smit, S. Kuy, C. G. Knight, and G. J. Cooper. 2006. Human colostrum: Identification of minor proteins in the aqueous phase by proteomics. Proteomics 6:2208-2216.

Patterson, S. D., and R. H. Aebersold. 2003. Proteomics: the first decade and beyond. Nat. Genet. 33(Suppl):311-323.

Perrin, C., C. Poirson, P. Bracquart, J. L. Gaillard, and C. Guimont 2000. Etablissement de l'empreinte protéique de base de Streptococcus thermophilus par 2D-PAGE. Sci. Aliments 20:97104.

Quiros, A., M. Ramos, B. Muguerza, M. A. Delgado, P. J. MartinAlvarez, A. Aleixandre, and I. Recio. 2006. Determination of the antihypertensive peptide LHLPLP in fermented milk by highperformance liquid chromatography-mass spectrometry. J. Dairy Sci. 89:4527-4535.

Quiros, A., M. Ramos, B. Muguerza, M. A. Delgado, M. Miguel, A. Aleixandre, and I. Recio. 2007. Identification of novel 
antihypertensive peptides in milk fermented with Enterococcus faecalis. Int. Dairy J. 17:33-41.

Reinhardt, T. A., and D. Lippolis. 2006. Bovine milk fat globule membrane proteome. J. Dairy Res. 73:406-416.

Reinhardt, T. A., and J. D. Lippolis. 2008. Developmental changes in the milk fat globule membrane proteome during the transition from colostrum to milk. J. Dairy Sci. 91:2307-2318.

Rizzello, C. G., L. Losito, M. Gobbetti, T. Carbonara, M. D. De Bari, and P. G. Zambonin. 2005. Antibacterial activities of peptides from the water-soluble extracts of Italian cheese varieties. J. Dairy Sci. 88:2348-2360.

Ross, P. L., Y. N. Huang, J. N. Marchese, B. Williamson, K. Parker, S. Hattan, N. Khainovski, S. Pillai, S. Dey, S. Daniels, S. Purkayastha, P. Juhasz, S. Martin, M. Bartlet-Jones, F. He, A. Jacobson, and D. J. Pappin. 2004. Multiplexed protein quantitation in Saccharomyces cerevisiae using amine-reactive isobaric tagging reagents. Mol. Cell. Proteomics 3:1154-1169.

Roy, K., M. Meyrand, G. Corthier, V. Monnet, and M.-Y. Mistou. 2008. Proteomic investigation of the adaptation of Lactococcus lactis to the mouse digestive tract. Proteomics 8:1661-1676.

Sachon, E., S. Mohammed, N. Bache, and O. N. Jensen. 2006. Phosphopeptide quantitation using amine-reactive isobaric tagging reagents and tandem mass spectrometry: Application to proteins isolated by gel electrophoresis. Rapid Commun. Mass Spectrom. 20:1127-1134

Sanchez, B., M. C. Champomier-Verges, P. Anglade, F. Baraige, C. G. de Los Reyes-Gavilan, A. Margolles, and M. Zagorec. 2005. Proteomic analysis of global changes in protein expression during bile salt exposure of Bifidobacterium longum NCIMB 8809. J. Bacteriol. 187:5799-5808

Sanchez, B., M. C. Champomier-Verges, M. D. Collado, P. Anglade, F. Baraige, Y. Sanz, C. G. D. L. Reyes-Gavilan, A. Margolles, and M. Zagorec. 2007a. Low-pH adaptation and the acid tolerance response of Bifidobacterium longum biotype longum. Appl. Environ. Microbiol. 73:6450-6459.

Sanchez, B., M. C. Champomier-Verges, B. Stuer-Lauridsen, P. Ruas-Madiedo, P. Anglade, F. Baraige, C. de los Reyes-Gavilan, E. Johansen, M. Zagorec, and A. Margolles. 2007b. Adaptation and response of Bifidobacterium animalis subsp. lactis to bile: A proteomic and physiological approach. Appl. Environ. Microbiol. 73:6757-6767.

Saz, J. M., and M. L. Marina. 2008. Application of micro- and nanoHPLC to the determination and characterization of bioactive and biomarker peptides. J. Sep. Sci. 31:446-458.

Scherl, A., P. Francois, Y. Charbonnier, J. Deshusses, T. Koessler, A. Huyghe, M. Bento, J. Stahl-Zeng, A. Fischer, A. Masselot, A. Vaezzadeh, F. Galle, A. Renzoni, P. Vaudaux, D. Lew, C. Zimmermann-Ivol, P. A. Binz, J. C. Sanchez, D. Hochstrasser, and J. Schrenzel. 2006. Exploring glycopeptide-resistance in Staphylococcus aureus: A combined proteomics and transcriptomics approach for the identification of resistance-related markers. BMC Genomics 7:296.

Singh, T. K., P. F. Fox, P. Hojrup, and A. Healy. 1994. A scheme for the fractionation of cheese nitrogen and identification of principal peptides. Int. Dairy J. 4:111-122.

Smolenski, G., S. Haines, F. Y. S. Kwan, J. Bond, V. Farr, S. R. Davis, K. Stelwagen, and T. T. Wheeler. 2007. Characterisation of host defence proteins in milk using a proteomic approach. J. Proteome Res. 6:207-215.

Soloviev, M., and P. Finch. 2005. Peptidomics, current status. J. Chromatogr. B Analyt. Technol. Biomed. Life Sci. 815:11-24.

Streit, F., J. Delettre, G. Corrieu, and C. Beal. 2008. Acid adaptation of Lactobacillus delbrueckii subsp. bulgaricus induces physiological responses at membrane and cytosolic levels that improves cryotolerance. J. Appl. Microbiol. 105:1071-1080.

Sui, J., T. L. Tan, J. Zhang, C. B. Ching, and W. N. Chen. 2007. iTRAQ-coupled 2D LC-MS/MS analysis on protein profile in vascular smooth muscle cells incubated with S- and R-enantiomers of propranolol: Possible role of metabolic enzymes involved in cellular anabolism and antioxidant activity. J. Proteome Res. 6:1643-1651

Ünlü, M., M. E. Morgan, and J. S. Minden. 1997. Difference gel electrophoresis: A single gel method for detecting changes in protein extracts. Electrophoresis 18:2071-2077.

Vitali, B., S. Turroni, F. Piaz, M. Candela, V. Wasinger, and P. Brigidi. 2007. Genetic and proteomic characterization of rifaximin resistance in Bifidobacterium infantis BI07. Res. Microbiol. 158:355-362.

Vitali, B., V. Wasinger, P. Brigidi, and M. Guilhaus. 2005. A proteomic view of Bifidobacterium infantis generated by multi-dimensional chromatography coupled with tandem mass spectrometry. Proteomics 5:1859-1867.

Wang, Y., M. Delettre, A. Guillot, G. Corrieu, and C. Beal. 2005. Influence of cooling temperature and duration on cold adaptation of Lactobacillus acidophilus RD758. Cryobiology 50:294-307.

Wedholm, A., H. S. Moller, H. Lindmark-Mansson, M. D. Rasmussen, A. Andren, and L. B. Larsen. 2008. Identification of peptides in milk as a result of proteolysis at different levels of somatic cell counts using LC MALDI MS/MS detection. J. Dairy Res. 75:7683.

Wolff, S., A. Otto, D. Albrecht, J. S. Zeng, K. Buttner, M. Gluckmann, M. Hecker, and R. Becher. 2006. Gel-free and gel-based proteomics in Bacillus subtilis - A comparative study. Mol. Cell. Proteomics 5:1183-1192

Wouters, J. A., H. Frenkiel, W. M. De Vos, O. P. Kuipers, and T. Abee. 2001. Cold shock proteins of Lactococcus lactis MG1363 are involved in cryoprotection and in the production of cold-induced proteins. Appl. Environ. Microbiol. 67:5171-5178.

Wu, W. W., G. H. Wang, S. J. Baek, and R. F. Shen. 2006. Comparative study of three proteomic quantitative methods, DIGE, cICAT, and iTRAQ, using 2D gel- or LC-MALDI TOF/TOF. J. Proteome Res. 5:651-658.

Yuan, J., B. Wang, Z. Sun, X. Bo, X. Yuan, X. He, H. Zhao, X. Du, F. Wang, Z. Jiang, L. Zhang, L. Jia, Y. Wang, K. Wei, J. Wang, X. Zhang, Y. Sun, L. Huang, and M. Zeng. 2008. Analysis of hostinducing proteome changes in Bifidobacterium longum NCC2705 grown in vivo. J. Proteome Res. 7:375-385.

Yuan, J., L. Zhu, X. K. Liu, Y. Zhang, T. Y. Ying, B. Wang, J. J. Wang, H. Dong, E. L. Feng, Q. Li, J. Wang, H. X. Wang, K. H. Wei, X. M. Zhang, C. F. Huang, P. T. Huang, L. Y. Huang M. Zeng, and H. L. Wang. 2006. A proteome reference map and proteomic analysis of Bifidobacterium longum NCC2705. Mol. Cell. Proteomics 5:1105-1118. 